\title{
Differential production of steroids by dispersed granulosa and theca interna cells from developing preovulatory follicles of pigs
}

\author{
B. K. Tsang*, L. Ainsworth $\dagger$, B. R. Downey $\ddagger$ and G. J. Marcus $\dagger$ \\ * Reproductive Biology Unit, Department of Obstetrics and Gynecology and Department of \\ Physiology, University of Ottawa, Ottawa Civic Hospital, Ottawa, Ontario, Canada KIY 4E9; \\ $\uparrow$ Animal Research Centre, Agriculture Canada, Ottawa, Ontario, Canada K1A 0C6; and \\ $\ddagger$ Department of Animal Science, Macdonald College of McGill University, Ste Anne de Bellevue, \\ Quebec, Canada H9X $1 \mathrm{CO}$
}

\begin{abstract}
Summary. Dispersed granulosa and theca interna cells were recovered from follicles of prepubertal gilts at 36,72 and $108 \mathrm{~h}$ after treatment with 750 i.u. PMSG, followed $72 \mathrm{~h}$ later with 500 i.u. hCG to stimulate follicular growth and ovulation. In the absence of aromatizable substrate, theca interna cells produced substantially more oestrogen than did granulosa cells. Oestrogen production was increased markedly in the presence of androstenedione and testosterone in granulosa cells but only to a limited extent in theca interna cells. The ability of both cellular compartments to produce oestrogen increased up to $72 \mathrm{~h}$ with androstenedione being the preferred substrate. Oestrogen production by the two cell types incubated together was greater than the sum produced when incubated alone. Theca interna cells were the principal source of androgen, predominantly androstenedione. Thecal androgen production increased with follicular development and was enhanced by addition of pregnenolone or by LH 36 and $72 \mathrm{~h}$ after PMSG treatment. The ability of granulosa and thecal cells to produce progesterone increased with follicular development and addition of pregnenolone. After exposure of developing follicles to hCG in vivo, both cell types lost their ability to produce oestrogen. Thecal cells continued to produce androgen and progesterone but no longer responded to $\mathbf{L H}$ in vitro. These studies indicate that several functional changes in the steroidogenic abilities of the granulosa and theca interna compartments occur during follicular maturation.
\end{abstract}

\section{Introduction}

The control of ovarian steroid synthesis and secretion during preovulatory follicular development is a complex process involving interaction of two follicular compartments, the membrana granulosa and the theca interna, as well as a co-ordinated sequence of actions by pituitary gonadotrophins (Armstrong \& Dorrington, 1977; Erickson, 1983). Follicular development involves cytodifferentiation characterized by marked biochemical and morphological changes which include acquisition of various hormone receptors and the development or alteration of the abilities for steroid synthesis and metabolism (Richards \& Midgley, 1976; Bjersing, 1978; Kumari \& Channing, 1979; McNatty, 1981).

Much attention has been given to the study of granulosa cell differentiation during follicular development in the pig (Channing, 1970; Channing \& Kammerman, 1973; Anderson, Schaerf \& Channing, 1979; Schwartz-Kripner \& Channing, 1979; Haney \& Schomberg, 1981). These studies 
involved cell culture or incubation of granulosa cell suspensions. In contrast, parallel studies on theca differentiation have involved explant cultures or incubation of thecal fragments (Haney \& Schomberg, 1981 ; Evans, Dobias, King \& Armstrong, 1981; Tsang, Moon \& Armstrong, 1982b). Therefore direct comparison of steroidogenic abilities and hormonal responsiveness could not be made with assurance that observed differences were not merely the result of the different states of tissue aggregation affecting solute and gas exchange. Interpretation of observations in these studies was also hindered by the fact that the tissues used were usually from abattoir material and so the stage of follicular development could only be estimated from the size of the follicles. Moreover, even when the follicular stage is known precisely, it may not be assumed that the metabolic profile, which characterizes the tissues at the time of their isolation from the follicle, is retained during culture periods for $24 \mathrm{~h}$ or more.

In previous studies we have demonstrated that prepubertal gilts treated with $\mathrm{PMSG} / \mathrm{hCG}$ produce large numbers of synchronously developing follicles which will ovulate at a predictable time. In these studies we charted the sequence of changes in follicular fluid concentrations of steroids (Ainsworth, Tsang, Downey, Marcus \& Armstrong, 1980), cyclic AMP and prostaglandins (Tsang, Ainsworth, Downey \& Armstrong, 1979) and in meiotic maturation of the oocyte during preovulatory development (Ainsworth et al., 1980). In the present studies, we have sought to characterize more precisely the steroidogenic abilities of dispersed theca interna and granulosa cells, at well-defined stages of follicular maturation until shortly before ovulation, by incubating the cells for short periods in a chemically defined medium with or without steroid precursors and gonadotrophins. A preliminary report of some of this work has been presented (Tsang, Ainsworth, Downey \& Marcus, 1982a).

\section{Materials and Methods}

Animal preparation. Groups of 4-8 prepubertal Landrace gilts, 4.0-4.5 months of age and weighing 60-70 kg, were treated intramuscularly with 750 i.u. PMSG (Equinex: Ayerst Labs, Montreal, Quebec) and $72 \mathrm{~h}$ later with 500 i.u. hCG (APL: Ayerst) to enhance follicular growth and ovulation. Laparotomies were carried out on groups of gilts 36,72 or $108 \mathrm{~h}$ after PMSG treatment and the ovaries removed as described previously (Ainsworth et al., 1980). At least 3 replicate experiments were performed for each time. One group of gilts was used per replicate.

Isolation and dispersion of follicular cells. After removal, the ovaries were transferred into icecold Hank's balanced salt solution (HBSS, modified; Flow Laboratories, Mississauga, Ontario) and follicles of uniform diameter $(36 \mathrm{~h}, 3-4 \mathrm{~mm} ; 72 \mathrm{~h}, 5-6 \mathrm{~mm} ; 108 \mathrm{~h}, 6-8 \mathrm{~mm})$ were dissected out, trimmed of stromal tissue and transferred into fresh medium. Initially, the gross appearance of dissected follicles was examined under the stereomicroscope for evidence of atresia. Follicles with a uniform translucent appearance and extensive vascularization were considered to be non-atretic. Non-atretic follicles were further characterized by having a regular granulosa layer which could be removed from the thecal wall in translucent sheets. Follicles not conforming to these criteria were discarded. The follicles were cut into halves or quarters, depending on size, and the granulosa cells gently scraped from the thecal wall with a fine wire loop, using stereomicroscopy. The theca interna and theca externa were then separated using fine forceps. Granulosa and theca interna layers from individual follicles were pooled separately and kept in ice-cold Hank's solution. Representative samples of the intact thecal layers and of isolated theca interna were taken from several replicate experiments, fixed in Helly's fluid, dehydrated, embedded in paraffin wax, sectioned and stained with haematoxylin and eosin. Histological examination showed the absence of granulosa cells from the intact follicle wall (Pl. 1, Fig. 1) and a good dissection of theca interna (Pl. 1, Fig. 2) from theca externa. 

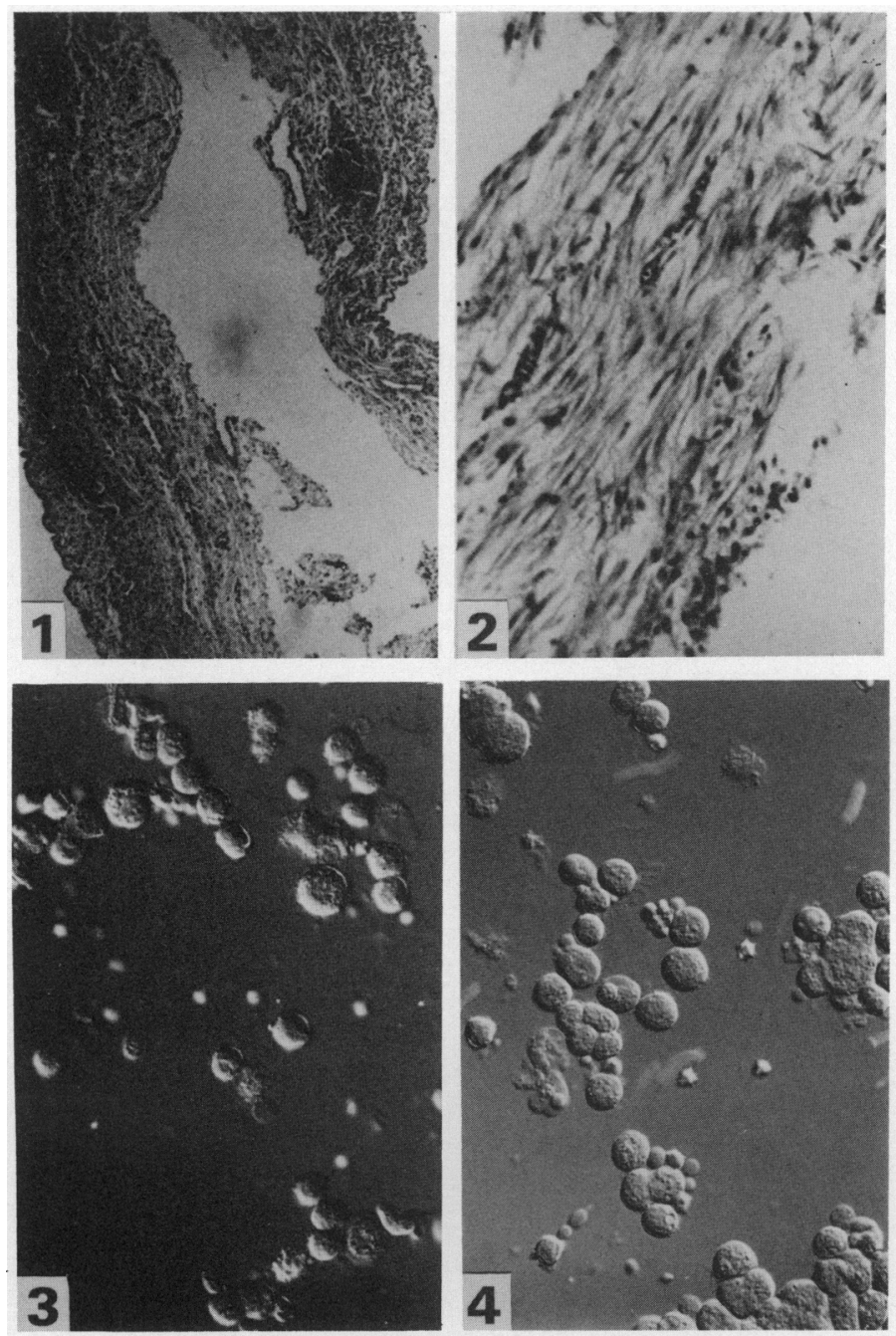

Fig. 1. Section of follicular wall after removal of granulosa cells. $\mathrm{H}$ and $\mathrm{E}$ stain, $\times 25$.

Fig. 2. Section of theca interna layer. $\mathrm{H}$ and $\mathrm{E}$ stain, $\times 150$.

Fig. 3. Dispersed theca interna cells. Nomarski, $\times 250$.

Fig. 4. Dispersed granulosa cells. Nomarski, $\times 250$. 
The pools of theca interna layers and granulosa cells were subjected to enzymic dissociation, after centrifugation at $150 \mathrm{~g}$ and decanting of the Hank's solution. Tissues were suspended in $10 \mathrm{ml}$ Moscona's buffer (Moscona, 1961), pH 7.4, containing 0.5\% crude collagenase (Type II: Sigma Chemical Co., St Louis, MO, U.S.A.), $0 \cdot 1 \%$ hyaluronidase (Type III : Sigma) and $0 \cdot 1 \%$ pronase (Protease Type XIV: Sigma) and $1 \%$ chicken serum and incubated at $37^{\circ} \mathrm{C}$ in a shaking water bath for 45-60 min. After $15 \mathrm{~min}$ of incubation, $\sim 1 \mathrm{mg}$ DNase (Type I: Sigma) was added and dissociation of cells was assisted by repeated pipetting of the suspensions with a Pasteur pipette. At the end of the incubation, $2 \mathrm{ml}$ fetal calf serum were added to each suspension. The cell suspensions were diluted $1: 1$ with HBSS and centrifuged for $5 \mathrm{~min}$ at $150 \mathrm{~g}$. The dispersed cells (Pl. 1, Figs $3 \&$ 4) were washed 3 times in HBSS by repeated suspension and centrifugation $(150 \mathrm{~g}, 5 \mathrm{~min})$ and finally resuspended in Eagle's Minimum Essential Medium (MEM; GIBCO Laboratories, Grand Island, NY, U.S.A.) as modified by Dorrington \& Armstrong (1975) but supplemented with 25 mM-Hepes buffer, and kept at $0^{\circ} \mathrm{C}$ until addition to incubation tubes.

The viability and concentration of the dispersed cells were determined by the fluorogenic ester hydrolysis procedure (Rotman \& Papermaster, 1966). Fluorescein diacetate was used as the fluorogenic ester and the number and proportion of fluorescing cells were determined with a haemocytometer using a Zeiss fluorescence microscope with incident u.v. illumination and KP490 excitation and LP20 barrier filters. Cell viability of granulosa and theca interna cells was $90-95 \%$ and $85-95 \%$, respectively.

Cell incubation. To examine the changes in steroidogenic abilities of ovarian follicular cells during preovulatory growth and maturation, 2.75-3.5 $\times 10^{5}$ dispersed granulosa or theca interna cells prepared 36,72 or $108 \mathrm{~h}$ after PMSG treatment were dispensed in triplicate into $12 \times 75 \mathrm{~mm}$ glass test tubes. The cells were incubated separately in $0.3 \mathrm{ml}$ or together in $0.6 \mathrm{ml}$ modified Eagle's $\mathrm{MEM}$ in air at $37^{\circ} \mathrm{C}$ for $6 \mathrm{~h}$ unless otherwise indicated. In some instances, androstenedione, testosterone or pregnenolone $(100 \mathrm{nM}-100 \mu \mathrm{M})$ and/or highly purified ovine LH (S-1390; activity $2 \times$ NIH-S14 containing < $0.02 \%$ oFSH (S1557BP)) or highly purified ovine FSH (S1557BP; activity $100 \times \mathrm{NIH}-\mathrm{S} 10$, containing $<0.5 \%$ oLH (S-1390)) were added to the incubation medium. Both gonadotrophin preparations were kindly donated by Dr M. R. Sairam, Clinical Research Institute of Montreal, Montreal, Quebec. At the end of the incubation period, $1.0 \mathrm{ml}$ absolute ethanol was added to each incubation tube to lyse the cells and precipitate cellular proteins. The supernatants were separated by centrifugation $(500 \mathrm{~g}, 15 \mathrm{~min})$ and stored at $-20^{\circ} \mathrm{C}$ until analyses.

Assays. Progesterone was determined using the antiserum and method described by Orczyk, Hichens, Arth \& Behrman (1979). This antiserum shows negligible cross-reactivity ( $<0.1 \%$ ) with androgens and oestrogens. Androstenedione and testosterone were assayed as described by Fortune \& Eppig (1979) and by Tsang, Armstrong \& Whitfield (1980), respectively. The androstenedione antiserum exhibits low cross-reactivity $(<1 \%)$ with neutral and phenolic steroids except for $5 \alpha$ androstene-3,17-dione $(5 \%)$ and testosterone $(2 \%)$. The testosterone antiserum cross-reacts significantly with other androgens, such as $17 \beta$-hydroxy-5 $\alpha$-androstane-3-one (DHT; 75\%), $5 \alpha$ androstane- $3 \alpha, 17 \beta$-diol $(17 \%)$, and $5 \alpha$-androstane-3 $\beta, 17 \beta$-diol $(10 \%)$ but not with progesterone $(<0.001 \%)$, oestradiol $(<0.01 \%)$ or other androgens $(<0.02 \%)$ : the assay therefore measures androgens (primarily testosterone and DHT) rather than testosterone. The antisera against oestradiol and oestrone have low cross-reactivity with other phenolic steroids $(<10 \%)$ and negligible cross-reactivity with neutral steroids $(<0.1 \%)$. The sensitivities of the assays for progesterone, androstenedione, testosterone + DHT, oestradiol and oestrone were $12 \cdot 5,25,25,2 \cdot 5$ and $5 \mathrm{pg}$, respectively. The intra- and inter-assay coefficients of variation of the assays were $<10 \%$ and $<15 \%$, respectively. Data presented in Text-figs $1-4$ have not been corrected for initial steroid content of cells. 
Statistical analyses. Results were treated by analysis of variance and Duncan's new multiple range test (Steel \& Torrie, 1960). When there was evidence of heterogeneity of variance, statistical analysis was performed on logarithmically transformed data. Tabulated results were analysed by a least squares procedure (Harvey, 1960) using a linear model to compare the effects of multiple variables and their interactions.

\section{Results}

\section{Oestrogen production}

In the absence of exogenous substrate, theca interna cells produced significant quantities of oestrone and oestradiol-17 $\beta$, particularly when isolated from follicles 36 and $72 \mathrm{~h}$ after PMSG treatment (Table 1). In contrast, granulosa cells from the same follicles produced negligible quantities of oestrogen. After exposure of the developing follicles to hCG in vivo, the ability of both cell preparations to produce oestrone and oestradiol was greatly diminished $(P<0.001)$.

Table 1. Steroid production in vitro by theca interna (TC) and granulosa (GC) cells in the absence of added substrate

\begin{tabular}{|c|c|c|c|c|c|c|c|}
\hline \multirow[b]{3}{*}{ Steroid } & \multirow[b]{3}{*}{$\begin{array}{l}\text { Cell } \\
\text { type }\end{array}$} & \multicolumn{3}{|c|}{ Net steroid production } & \multirow{2}{*}{\multicolumn{3}{|c|}{ Summary of ANOVA }} \\
\hline & & \multicolumn{3}{|c|}{ Time after PMSG treatment } & & & \\
\hline & & $36 \mathrm{~h}$ & $72 \mathrm{~h}$ & $108 \mathrm{~h}$ & $\begin{array}{l}\text { Effect of } \\
\text { cell type }\end{array}$ & $\begin{array}{c}\text { Effect of } \\
\text { time }\end{array}$ & $\begin{array}{l}\text { Inter- } \\
\text { actions }\end{array}$ \\
\hline $\begin{array}{l}\text { Progesterone } \\
\text { (ng/10 cells) }\end{array}$ & $\begin{array}{l}\text { GC } \\
\text { TC }\end{array}$ & $\begin{array}{l}2.92 \pm 0.97(4) \\
0.15 \pm 0.05(4)\end{array}$ & $\begin{array}{l}6.07 \pm 2.32 \\
0.03 \pm 0.01\end{array}$ & $\begin{array}{c}40 \cdot 10 \pm 11 \cdot 80(4) \\
6 \cdot 12 \pm 2 \cdot 28(4)\end{array}$ & $P<0.01$ & $P<0.01$ & $P<0.025$ \\
\hline $\begin{array}{l}\text { Androstenedione } \\
\text { (ng/10 } 10^{5} \text { cells) }\end{array}$ & $\begin{array}{l}\text { GC } \\
\text { TC }\end{array}$ & $\begin{array}{l}0.01 \pm 0.00 \\
0.50 \pm 0.19\end{array}$ & $\begin{array}{l}0.01 \pm 0.00(5) \\
1.93 \pm 1.33(5)\end{array}$ & $\begin{array}{l}0.03 \pm 0.01 \\
9.21 \pm 2.23(4)\end{array}$ & $P<0.001$ & $P<0.001$ & $P<0.001$ \\
\hline $\begin{array}{l}\text { Testosterone } \\
+ \text { DHT } \\
\left.\text { ( } \mathrm{pg} / 10^{5} \text { cells }\right)\end{array}$ & $\begin{array}{l}\text { GC } \\
\text { TC }\end{array}$ & $\begin{array}{r}9 \cdot 77 \pm 2 \cdot 82(5) \\
15 \cdot 60 \pm 4 \cdot 40(5)\end{array}$ & $\begin{array}{l}12 \cdot 60 \pm 3 \cdot 90(3) \\
29 \cdot 80 \pm 13 \cdot 20(3)\end{array}$ & $\begin{array}{c}8.85 \pm 0.74(4) \\
88.80 \pm 28.50(4)\end{array}$ & $P<0.001$ & $P<0.001$ & $P<0.001$ \\
\hline $\begin{array}{l}\text { Oestrone } \\
\quad\left(\mathrm{pg} / 10^{5} \text { cells }\right)\end{array}$ & $\begin{array}{l}\text { GC } \\
\text { TC }\end{array}$ & $\begin{array}{cc}14 \cdot 30 \pm 3 \cdot 50 & (3) \\
128 \pm 4 & (3)\end{array}$ & $\begin{array}{c}40.40 \pm 13.40(8) \\
151 \pm 4.90(8)\end{array}$ & $\begin{array}{l}1.90 \pm 0.70 \\
6.30 \pm 1.10\end{array}$ & $P<0.01$ & $P<0.001$ & NS \\
\hline $\begin{array}{l}\text { Oestradiol } \\
\quad\left(\mathrm{pg} / 10^{5} \text { cells }\right)\end{array}$ & $\begin{array}{l}\text { GC } \\
\text { TC }\end{array}$ & $\begin{array}{c}41 \cdot 30 \pm 23 \cdot 30(3) \\
332 \pm 152(3)\end{array}$ & $\begin{array}{c}36 \cdot 90 \pm 9.80(8) \\
359 \pm 78(8)\end{array}$ & $\begin{array}{r}1.50 \pm 0.60(3) \\
15.90 \pm 5.20(3)\end{array}$ & $P<0.01$ & $P<0.001$ & NS \\
\hline
\end{tabular}

Values are mean \pm s.e.m. Number in parentheses indicates number of replicates, each done in triplicate incubations of 300000 cells collected at the indicated times and incubated for $6 \mathrm{~h}$ in $0.3 \mathrm{ml}$ medium.

Addition of testosterone or androstenedione $(0-100 \mu \mathrm{M})$ resulted in concentration-dependent increases in production of oestradiol and oestrone by granulosa cells obtained 36 and $72 \mathrm{~h}$ after PMSG treatment (Text-figs $1 \& 2$ ). In addition to the significant influence of the stage of follicle development $(P<0.001)$ and aromatizable substrate $(P<0.001)$, there was also significant interaction $(P<0.001)$ between these factors due to the loss in the ability of androgen to stimulate oestrogen production $108 \mathrm{~h}$ after PMSG. Theca interna oestrogen production also increased significantly in the presence of androstenedione and testosterone (Text-figs 1 \& 2). However, this stimulation was substantially less than that in granulosa cells, at the same substrate concentrations. LH, but not FSH, stimulated $(P<0.025)$ oestrogen production in vitro by theca interna cells obtained $72 \mathrm{~h}$ after PMSG treatment (Table 2), but neither gonadotrophin affected oestrogen production by the thecal or granulosa cell in the presence of exogenous androstenedione $(10 \mu \mathrm{M})$ (data not shown). When incubated together, granulosa and theca interna cells produced larger amounts of oestrogen per cell than the sum produced by each incubated alone (Table 2). 

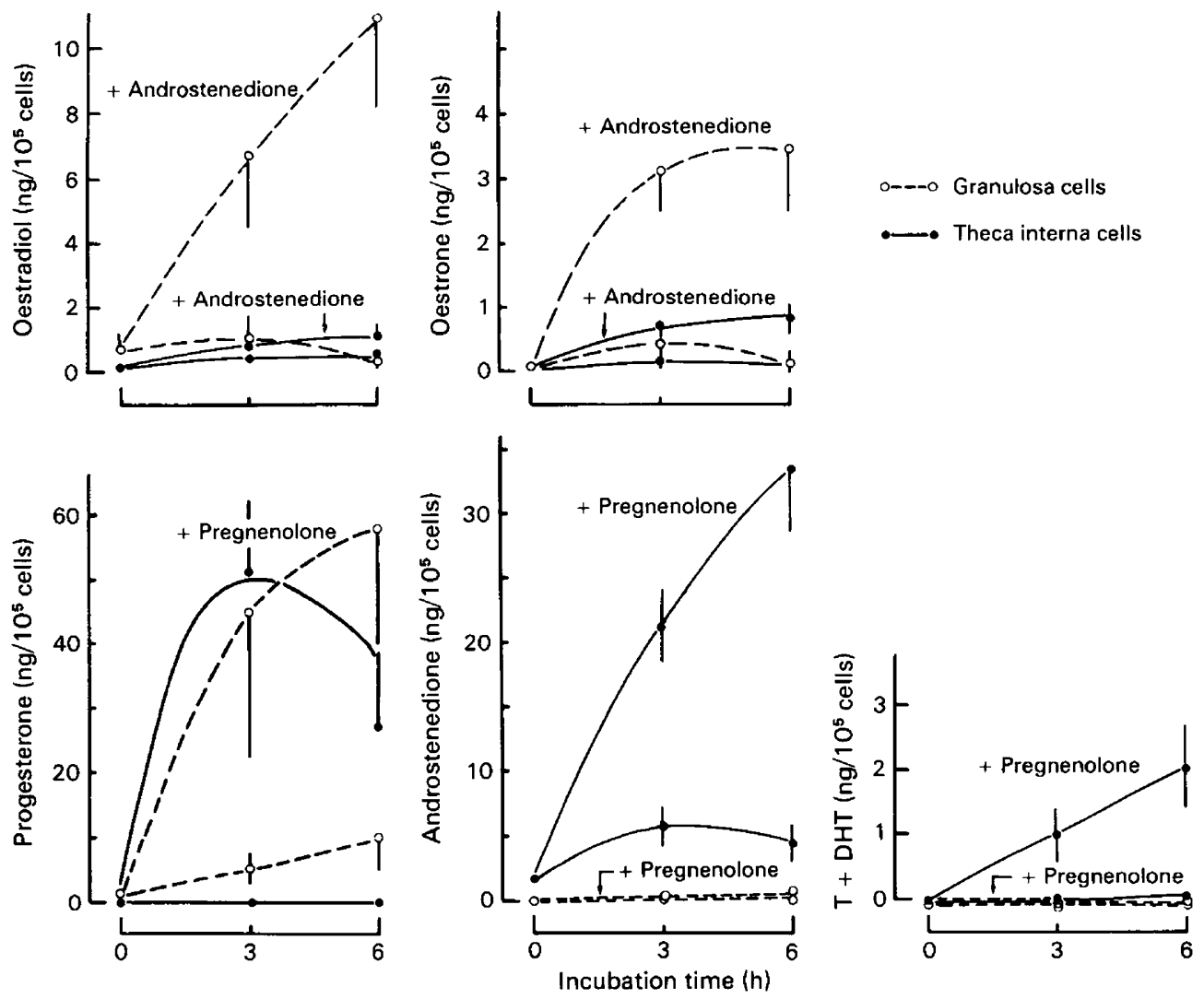

Text-fig. 1. Effects of incubation time and $10 \mu \mathrm{M}$ exogenous substrate (pregnenolone for progesterone, androstenedione and testosterone $(\mathrm{T})+$ DHT production; androstenedione for oestradiol-17 $\beta$ and oestrone production) on steroid production by dispersed granulosa $(\mathrm{O}----\mathrm{O})$ and theca interna (-O) cells obtained from follicles of gilts $72 \mathrm{~h}$ after PMSG injection. Each point represents the mean \pm s.e.m. of 3-8 replicates.

Table 2. Oestrogen production by theca interna and granulosa cells incubated separately and together with and without gonadotrophin

\begin{tabular}{lccccc}
\hline & \multicolumn{4}{c}{ Total oestrogen production $\dagger$} \\
\cline { 2 - 3 } & \multicolumn{2}{c}{$\mathrm{pg} / 10^{5}$ cells } & & $\mathrm{pg} / 2 \times 10^{5}$ cells \\
\cline { 2 - 3 } \cline { 5 - 6 } Treatment & Granulosa & Theca & & Sum $\ddagger$ & Coincubation \\
\hline None (control) & 62 & 553 & 615 & 2072 \\
FSH (100 ng/ml) & 38 & 784 & 820 & 2309 \\
LH (10 ng/ml) & 71 & 1022 & 1099 & 3290 \\
Standard error & $12-23$ & $114-222$ & 216 & 474 \\
\hline
\end{tabular}

(1) Effect of coincubation (sum $v$ s coincubation): $P<0.001$; (2) effect of FSH: $P>0.05$; (3) effect of LH: $P<0.025$; (4) interaction (coincubation and gonadotrophin): $P>0.05$

† Oestrone plus oestradiol produced in $6 \mathrm{~h}$ by cells collected $72 \mathrm{~h}$ after PMSG treatment (corrected for cell content before incubation).

$¥$ The least square means of the sum of oestrogen production by granulosa and theca interna cells incubated separately (6 replicates).

$\S$ The least square means of oestrogen production by granulosa and theca interna cells incubated together (5 replicates). 


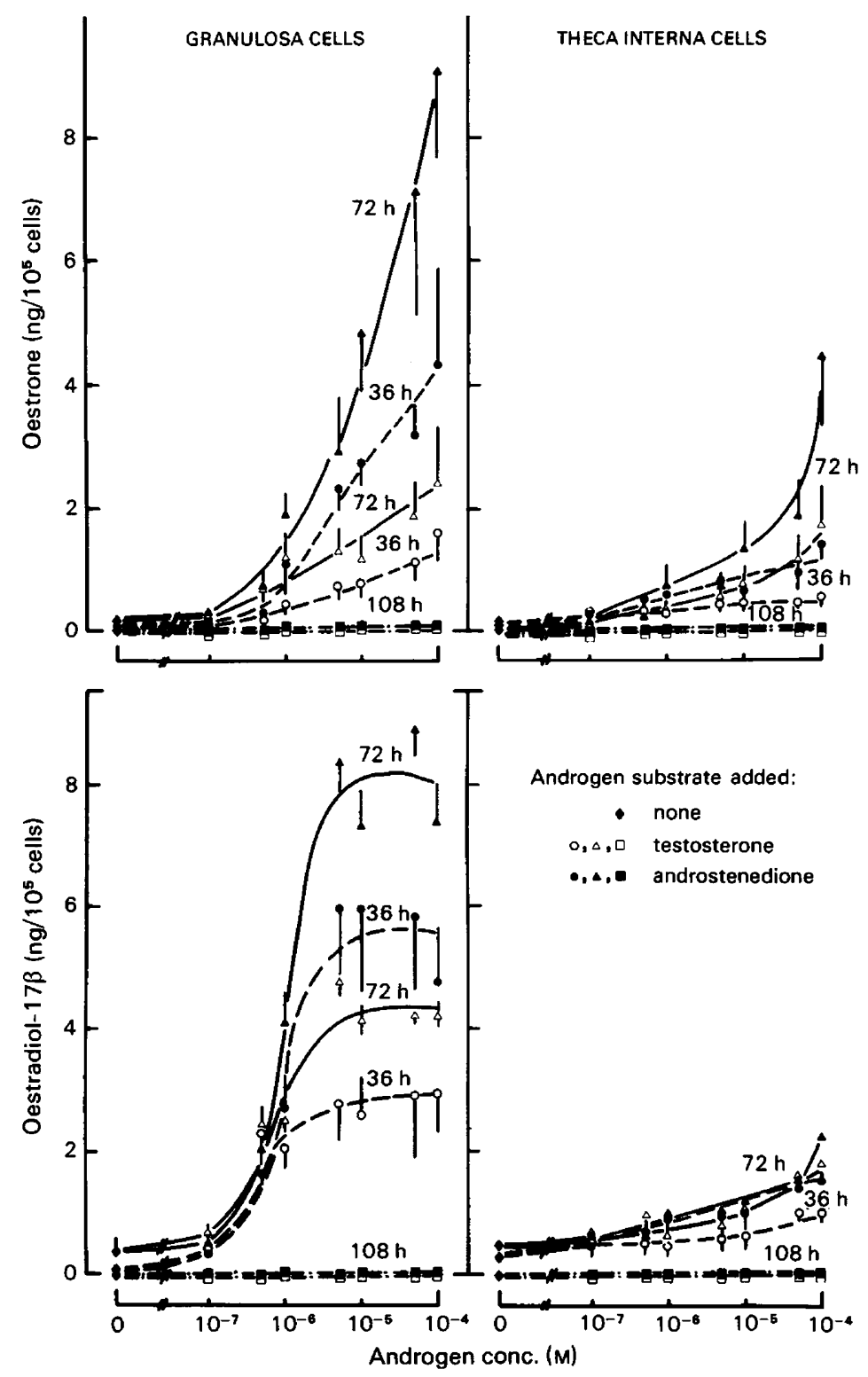

Text-fig. 2. Oestrone and oestradiol production during a 6-h incubation in the presence of different concentrations of exogenous aromatizable substrate by dispersed pig granulosa (GC) and theca interna cells (TC) isolated from follicles of gilts 36,72 and $108 \mathrm{~h}$ after PMSG/hCG treatment. The oestrogen content $\left(\mathrm{pg} / 10^{5}\right.$ cells) of the cells at these times before incubation was: oestrone: $1.53 \pm 0.91,46 \pm 31$ and $0.69 \pm 0.37$ in GC; $3.11 \pm 2.41,19 \pm 5$ and $1.28 \pm 0.75$ in TC; oestradiol: $5.97 \pm 2.78,152 \pm 41$ and $3.50 \pm 0.30$ in GC; $11.4 \pm 4.8,108 \pm 64$ and $1.60 \pm$ 1.00 in TC. Each point represents the mean \pm s.e.m. of 3-7 replicates. 


\section{Androgen production}

In the absence of exogenous substrate, theca interna cells produced significant quantities of androstenedione and testosterone + DHT, the production of androstenedione being 50 to 100 times greater than that of testosterone + DHT (Table 1). Androgen production by theca interna cells increased significantly $(P<0.001)$ with follicular development; addition of pregnenolone significantly increased androstenedione and testosterone + DHT production in a concentrationdependent manner at 36 and $72 \mathrm{~h}$, but not at $108 \mathrm{~h}$, after PMSG treatment (Text-figs 1 \& 3).

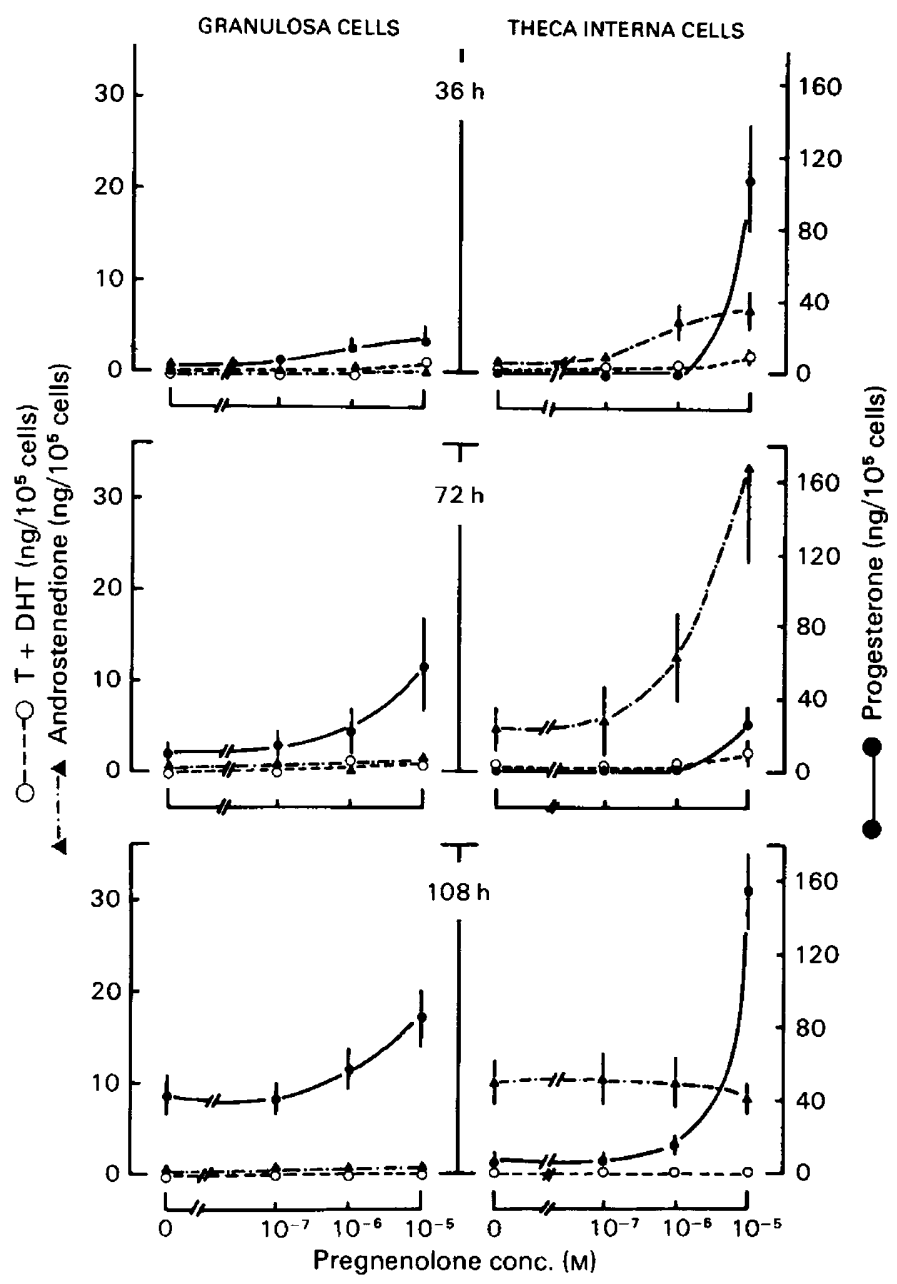

Text-fig. 3. Progesterone, androstenedione and testosterone $(\mathrm{T})+$ DHT production during a 6-h incubation in the presence of different concentrations of pregnenolone by dispersed pig granulosa (GC) and theca interna (TC) cells isolated from follicles of gilts 36,72 and $108 \mathrm{~h}$ after PMSG/hCG treatment. The steroid content of the cells at these times before incubation was: progesterone (ng/ $10^{5}$ cells): $0.40 \pm 0.26,1.27 \pm 0.49$ and $2.21 \pm 0.41$ in $\mathrm{GC} ; 0.05 \pm 0.03,0.09$ \pm 0.02 and $0.94 \pm 0.15$ in TC; androstenedione (ng/ $10^{5}$ cells): $0.04 \pm 0.01,0.06 \pm 0.02$ and $0.02 \pm 0.00$ in GC; $0.74 \pm 0.41,2.76 \pm 1.56$ and $0.93 \pm 0.38$ in $\mathrm{TC}$; testosterone + DHT $\left(\mathrm{pg} / 10^{5}\right.$ cells): $9.85 \pm 4.76,12.1 \pm 1.76$ and $5.71 \pm 2.01$ in GC; $63.9 \pm 46.0,23.0 \pm 3.49$ and $12.0 \pm 3.50$ in TC. Each point represents the mean \pm s.e.m. of $4-\overline{5}$ replicates. 
Addition of $\mathrm{LH}$ in vitro produced a concentration-dependent stimulation $(P<0.001)$ of androstenedione (Text-fig. 4b) and testosterone + DHT production (data not shown), in the absence but not the presence $(10 \mu \mathrm{M}, P>0.05)$ of pregnenolone, by theca interna cells obtained from follicles 36 and $72 \mathrm{~h}$ after PMSG treatment. FSH was stimulatory $(P<0.01)$ only at a concentration of $1 \mu \mathrm{g} / \mathrm{ml}$. Neither gonadotrophin nor pregnenolone affected androgen production by theca interna cells obtained $108 \mathrm{~h}$ after PMSG treatment. In contrast, granulosa cells from the same follicles produced negligible quantities of androgen at any stage of follicular development, whether or not pregnenolone and/or gonadotrophins were added (Table 1; Text-figs 3 \& 4b).

\section{Progesterone production}

Granulosa cells produced more progesterone than did theca interna cells (Table 1; Text-fig. 1). In the presence of pregnenolone, progesterone production by both cell preparations was increased significantly $(P<0.001)$, particularly at higher substrate concentrations (Text-fig. 3). However, whereas production of progesterone by granulosa cells increased progressively with follicular development, apparent thecal progesterone production was significantly lower at $72 \mathrm{~h}$ than at $36 \mathrm{~h}$ or $108 \mathrm{~h}$ after PMSG treatment $(P<0.001)$.

Addition of LH, in the absence of exogenous substrate, resulted in a significant increase $(P<$ $0.01)$ in progesterone production by theca interna cells 36 and $72 \mathrm{~h}$ after PMSG treatment although the response appeared to be markedly lower at the later stage (Text-fig. 4a). FSH was without effect except at high concentration $(1 \mu \mathrm{g} / \mathrm{ml})$. Neither gonadotrophin had a significant effect on progesterone production by theca cells collected $108 \mathrm{~h}$ after PMSG treatment $(P>0.05)$. There were no significant effects $(P>0.05)$ of FSH or LH on progesterone production by granulosa cells (Text-fig. 4a).

\section{Discussion}

The present study shows that pig granulosa cells have very little ability to synthesize oestrogen in vitro in the absence of added aromatizable substrate (Table 1). Addition of androstenedione or testosterone significantly increased their ability to produce oestrogen (Text-fig. 2). These findings are consistent with those of others for the pig (Anderson et al., 1979; Schomberg, 1979; Evans et al., 1981 ; Stoklosowa, Gregoraszczuk \& Channing, 1982; Tsang et al., 1982b) and for other species (Lacroix, Eechaute \& Leusen, 1974; Dorrington, Moon \& Armstrong, 1975; Erickson \& Ryan, 1975; Moor, 1977; Fortune \& Armstrong, 1978; Moon, Tsang, Simpson \& Armstrong, 1978; McNatty, Makris, de Grazia, Osathanondh \& Ryan, 1979a, b; Tsang et al., 1980). While these observations confirm reports that the inability of granulosa cells to produce oestrogens is due to the lack of the enzymic machinery necessary to convert $C_{21}$ steroids to androgens (Short, 1962; Bjersing \& Carstensen, 1967), Johnson \& Hoversland (1983) have shown that rat granulosa cells produce significant amounts of oestrogen in the absence of added androgen provided that NAD is available in the incubation medium.

In contrast, theca interna cells produced significant quantities of oestrogen in the absence of added androgen (Table 1). Although addition of androgen significantly increased thecal oestrogen production, these increases were substantially less $(\sim \times 10)$ than those produced in granulosa cells $(\sim \times 200)$ by the same additions (Text-fig. 2$)$. These results are in agreement with those of Evans $e t$ al. (1981) and Stoklosowa et al. (1982) but differ from those of Haney \& Schomberg (1981), who found no effect of added testosterone on thecal oestrogen production in organ culture and used this lack of response to indicate the effectiveness of separation of granulosa and thecal components. In the present work, although the possibility of granulosa cell contamination of thecal preparations cannot be completely excluded, the histological criteria (Plate 1) and the differences in oestrogen production by the two cell types when androgen is supplied, indicate that contamination would be $<5 \%$, which would be insufficient to affect the interpretation of results. 


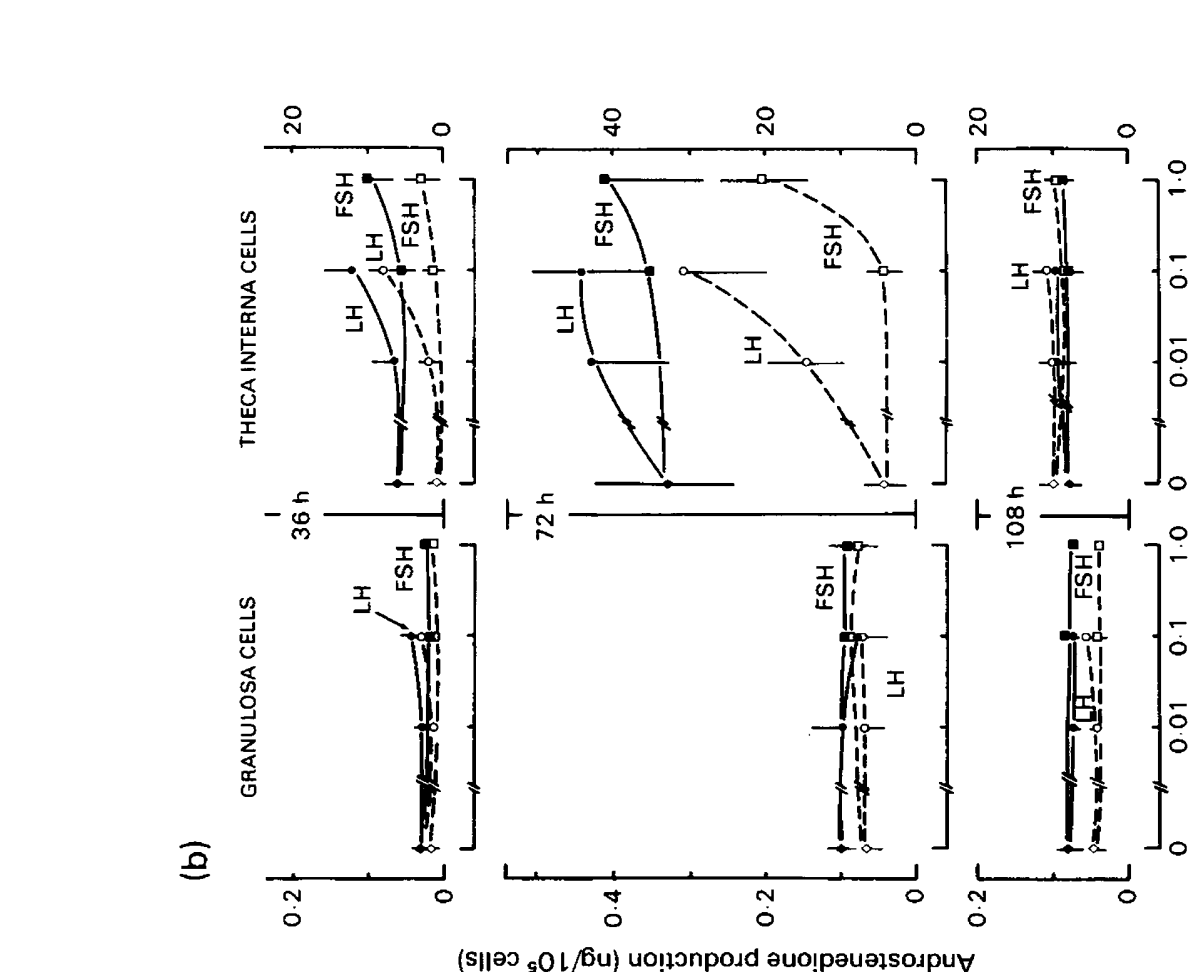

도옹ㅇㅇ

윤 영

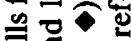

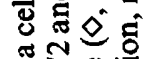

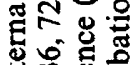

党焉

\%

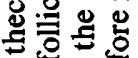

छ.

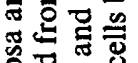

ठ웡

葛.

$60 \div$

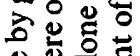

5

خु

芯芯

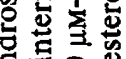

등응

हิ 矛导总

ن

$\Phi$

范 击

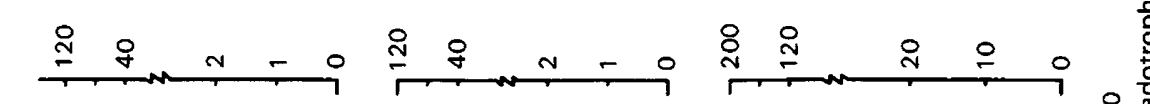

웅윽푼

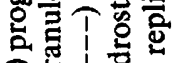

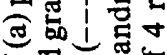
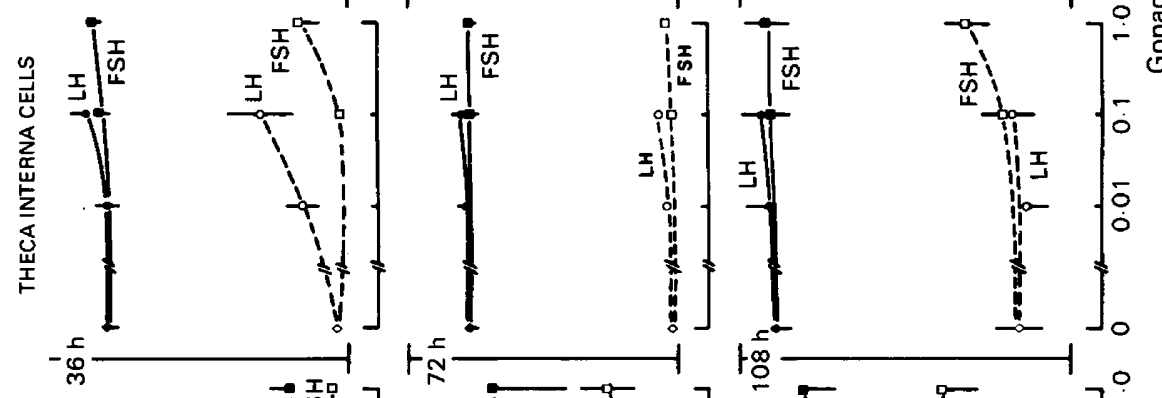

멍 可

ธี

员余宫

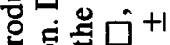

형민

오옳

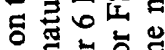

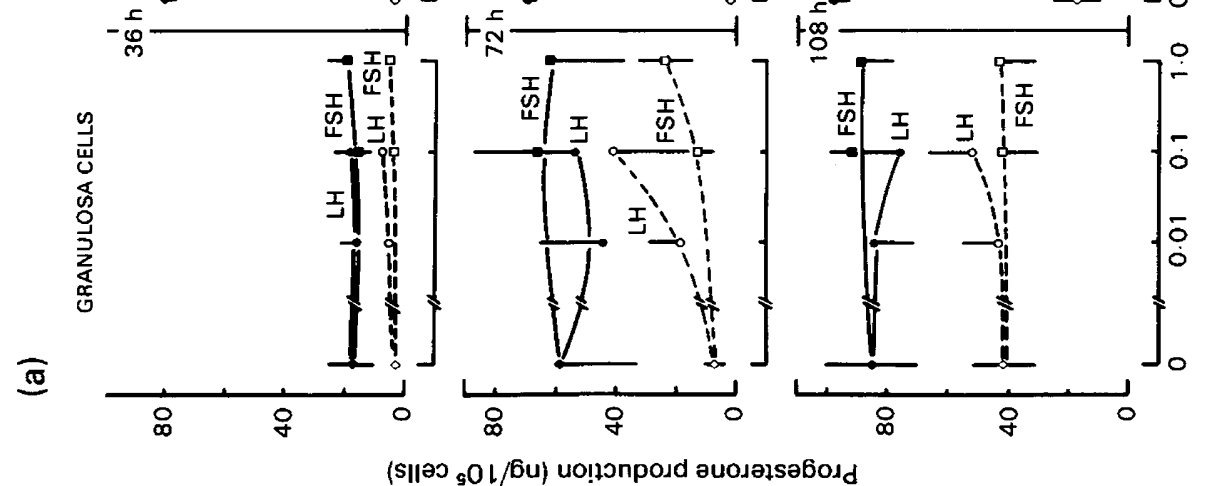

논융원

:

㤩要寻至总

둥로원

인면

원

을 영

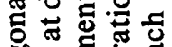

品焉焉

○导导的

둥요

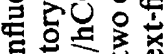

再可

的足 0

象造造

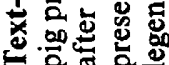


The finding that total oestrogen production by combined granulosa and thecal cells in the absence of added androgen (Table 2) was substantially greater than when the cells were incubated separately supports the two-cell hypothesis of follicular oestrogen production (Ryan, 1979) and establishes the theca interna as the principal source of androgen. This synergism between the cellular compartments indicates that the granulosa contribution to total follicular oestrogen production in vivo depends largely on the availability of androgen from the theca. It is therefore likely that the granulosa contribution to total follicular oestrogen in vivo increases significantly as the follicle matures, due to the greater number of granulosa cells per follicle (Daguet, 1978) and the progressive increase in granulosa aromatase activity and thecal androgen production.

The lack of significant androgen production by granulosa cells, even in the presence of pregnenolone or gonadotrophin (Table 1; Text-figs $3 \& 4 \mathrm{~b}$ ) confirms our earlier findings (Tsang et $a l ., 1982 b$ ) and those of Evans et al. (1981). However, the results conflict with those of Stoklosowa et al. (1982) who regarded the granulosa compartments to be a significant source of androgen because they found only twice as much androgen was produced by thecal cells. However, the androgen measured in that study was mainly testosterone + DHT and $5 \alpha$-reduced androgens. In the present work, testosterone + DHT production by thecal cells was also only about twice that of granulosa cells but total androgen production was up to 200 times greater (Table 1).

Progesterone production by granulosa cells in the absence of pregnenolone increased progressively with follicular maturation (Table 1; Text-fig. 3). The marked increase in progesterone production by granulosa cells after exposure to $\mathrm{LH} / \mathrm{hCG}$ in vivo, with or without added pregnenolone, is consistent with the findings of others (Channing, Brinkley \& Young, 1980; Haney \& Schomberg, 1981 ; Evans et al., 1981). However, progesterone production by granulosa cells was not increased by addition of $\mathrm{LH}$ or FSH in vitro, which contrasts with the marked response obtained by Evans et al. (1981). The reasons for this apparent discrepancy are not clear. Nevertheless, the results indicate that the steroidogenic ability of the granulosa cell after exposure to $\mathrm{LH} / \mathrm{hCG}$ in vivo changes, losing its oestrogenic character and, with luteinization, becomes progestagenic.

The observed pattern of changes in thecal androgen and progesterone production with follicular maturation extends the results of Evans et al. (1981) and Haney \& Schomberg (1981). In the absence of exogenous substrate, theca interna cells produced more androgen than progesterone at all stages (Table 1). Pregnenolone stimulated the production of both progesterone and androgen by thecal cells isolated 36 and $72 \mathrm{~h}$ after PMSG. By $72 \mathrm{~h}$ however, the ability of thecal cells to produce androgen was increased to the extent that there was no significant accumulation of progesterone, and androstenedione was the major steroid produced. LH stimulated progesterone production by theca only in the absence of pregnenolone, suggesting that the principal action of LH is to increase the availability of pregnenolone. This is consistent with the known action of LH on cholesterol sidechain cleavage (Channing \& Tsafriri, 1977). FSH had no effect except at high concentrations, suggesting that its action may be due to contamination by $\mathrm{LH}$.

By $108 \mathrm{~h}$ after PMSG, i.e. $36 \mathrm{~h}$ after treatment with hCG in vivo, LH no longer stimulated steroidogenesis and pregnenolone stimulated only progesterone production. Before hCG injection, both follicular compartments were capable of oestrogen production which could be enhanced by the addition of androgen. However, oestrogen production was markedly reduced by $108 \mathrm{~h}$ and could no longer be stimulated (Text-fig. 2; Table 1), despite continued production of significant amounts of androgen by the thecal cells (Table 1; Text-fig. 3). These steroidogenic activities are consistent with the pattern of changes in the content of steroids in follicular fluid obtained at different stages of follicular maturation in the pig (Ainsworth et al., 1980).

The loss of responsiveness to LH in vitro after exposure to the action of this hormone in vivo has been noted previously with rat follicles (Lamprecht, Zor, Tsafriri \& Lindner, 1973) and with human thecal tissues (Dennefors, Hamberger \& Nilsson, 1983). Moreover, Webb \& England (1982) have shown that, in sheep follicles, exposure to endogenous LH is followed by a sharp reduction in the concentration of $\mathrm{LH}$ receptors in both granulosa and thecal cells. Similarly, curtailment of 
oestrogen production has been noted in rat follicles after in-vivo exposure to LH (Lieberman et al., 1975; Hamberger, Hillensjo \& Ahren, 1978) and in sheep follicles after exposure to LH in vitro (Moor, 1974) or in vivo (Webb \& England, 1982). While the mechanism by which LH brings about these changes is not well understood, the reduction in oestrogen production in the rat ovary has been attributed to a decline in the availability of aromatizable androgen, associated with a reduction in the activity of the $17 \alpha$-hydroxylase $/ C_{17,20}$-lyase system which is essential for the conversion of $\mathrm{C}_{21}$ steroids to androgens (Hamberger et al., 1978; Suzuki \& Tamaoki, 1983; Weiss \& Eckstein, 1983). These results are inconsistent with the present findings whereby thecal production of androgen was sustained after exposure to hCG in vivo (Table 1). However, there was essentially no net increase in androgen production by thecal cells in the presence of added pregnenolone (Textfig. 3). These results suggest the possibility of end-product inhibition by androgen of the conversion of $\mathrm{C}_{21}$ steroids to androgens, with the result that progesterone accumulates. It is clear, nevertheless, that the decline in oestrogen production in the pig follicle is due primarily to a decrease in the aromatase activity of both cellular compartments. Whether this is accompanied by a change in activity of $17 \alpha$-hydroxylase and/or $\mathrm{C}_{17,20}$-lyase activities remains to be clarified.

In summary, our study of isolated cells from pig follicles have revealed several functional changes in steroidogenesis which occur during follicular maturation. The granulosa and theca interna cells of the developing preovulatory follicle of the pig produce oestrogen. The relative rate of production of oestrogen by each cell type is dependent on the stage of development of the follicle and availability of aromatizable substrate. The theca interna is the principal source of androgen and as such controls de-novo oestrogen production by providing aromatizable substrate. Although the granulosa cells appear to be the principal source of progesterone, theca interna cells also contribute significantly to follicular progesterone production. After exposure of the follicle to hCG in vivo, the aromatase activity of both cell types declines. The theca interna continues to produce progesterone and androgen whereas the granulosa cells are transformed from oestrogen-producing cells to ones producing primarily progesterone.

We thank Dr M. R. Sairam (Clinical Research Institute of Montreal, Montreal, Quebec) for the generous donation of purified preparations of ovine FSH and LH; Dr D. T. Armstrong (University of Western Ontario, London, Ontario) for the antisera for the steroid radioimmunoassays; Mrs C. Henderson, Dr R. Lucis, Ms Q. S. Lu, Ms S. McIntyre, Mr A. Peirce, Mr J. Pika and Mr G. Rogers for technical assistance; and Ms E. Chen for help in the preparation of the manuscript.

Contribution No. 1197, Animal Research Centre. Supported by a research contract from Agriculture Canada (OSU81-00135) and a grant from the Medical Research Council of Canada (MA-7793).

\section{References}

Ainsworth, L., Tsang, B.K., Downey, B.R., Marcus, G.J. \& Armstrong, D.T. (1980) Interrelationships between follicular fluid steroid levels, gonadotrophic stimuli, and oocyte maturation during preovulatory development of porcine follicles. Biol. Reprod. 23, 621-627

Anderson, L.D., Schaerf, F.W. \& Channing, C.P. (1979) Effects of follicular development on the ability of cultured porcine granulosa cells to convert androgens to estrogens. In Ovarian Follicular and Corpus Luteum Function, pp. 187-195. Eds C. P. Channing, J. Marsh \& W. A. Sadler. Plenum Press, New York.

Armstrong, D.T. \& Dorrington, J.H. (1977) Estrogen biosynthesis in the ovaries and testes. In Advances in Sex Hormone Research, vol. 3, pp. 217-258. Eds J. A. Thomas \& R. L. Singhal. University Park Press, Baltimore.
Bjersing, L. (1978) Maturation, morphology and endocrine function of the follicular wall in mammals. In The Vertebrate Ovary, pp. 181-214. Ed. R. E. Jones, Plenum Press, New York.

Bjersing, L. \& Carstensen, H. (1967) Biosynthesis of steroids by granulosa cells of the porcine ovary in vitro. J. Reprod. Fert. 14, 101-111.

Channing, C. P. (1970) Effects of stage of estrous cycle and gonadotropins upon luteinization of porcine granulosa cells in culture. Endocrinology 87, 156164.

Channing, C.P. \& Kammerman, S. (1973) Characteristics of gonadotropin receptors of porcine granulosa cells during follicle maturation. Endocrinology 92, 531540.

Channing, C.P. \& Tsafriri, A. (1977) Mechanism of action Downloaded from Bioscientifica.com at 04/26/2023 10:40:39AM 
of luteinizing hormone and follicle-stimulating hormone on the ovary in vitro. Metabolism 26, 413-468.

Channing, C.P., Brinkley, H.J. \& Young, E.P. (1980) Relationship between serum luteinizing hormone levels and the ability of porcine granulosa cells to luteinize and respond to exogenous luteinizing hormone in culture. Endocrinology 106, 317-322.

Daguet, M. C. (1978) Some aspects of final follicle growth in the sow. Annls Biol. anim. Biochim. Biophys. 18, 1343-1349.

Dennefors, B.L., Hamberger, L. \& Nilsson, L. (1983) Influence of human chorionic gonadotropin in vivo on steroid formation and gonadotropin responsiveness of isolated human preovulatory follicular cells. Fert. Steril. 39, 56-61.

Dorrington, J.H. \& Armstrong, D.T. (1975) Folliclestimulating hormone stimulates estradiol- $17 \beta$ synthesis in cultured Sertoli cells. Proc. natn. Acad. Sci. U.S.A. 72, 2667-2681.

Dorrington, J.H., Moon, Y.S. \& Armstrong, D.T. (1975) Estradiol-17 $\beta$ biosynthesis in cultured granulosa cells from hypophysectomized immature rats; stimulation by follicle-stimulating hormone. Endocrinology 97, 1328-1331

Erickson, G.F. (1983) Primary cultures of ovarian cells in serum-free medium as models of hormone-dependent differentiation. Molec. cell. Endocr. 29, 21-49.

Erickson, G.F. \& Ryan, K.J. (1975) The effect of LH/FSH, dibutyryl cyclic AMP, and prostaglandins on the production of estrogens by rabbit granulosa cells in vitro. Endocrinology 97, 108-113.

Evans, G., Dobias, M., King, G.J. \& Armstrong, D.T. (1981) Estrogen, anddrogen, and progesterone biosynthesis by theca and granulosa of preovulatory follicles in the pig. Biol. Reprod. 25, 673-682.

Fortune, J.E. \& Armstrong, D.T. (1978) Hormonal control of estradiol-17 $\beta$ biosynthesis in proestrous rat follicles: estradiol production by isolated theca vs. granulosa. Endocrinology 102, 227-235.

Fortune, J.E. \& Eppig, J.J. (1979) Effects of gonadotropins on steroid secrection by infantile and juvenile mouse ovaries in vitro. Endocrinology 105, 760-768.

Hamberger, L., Hillensjo, T. \& Ahren, K. (1978) Steroidogenesis in isolated cells of preovulatory rat follicles. Endocrinology 103, 771-777.

Haney, A.F. \& Schomberg, D.W. (1981) Estrogen and progesterone production by developing porcine follicles in vitro: evidence for estrogen formation by theca. Endocrinology 109, 971-977.

Harvey, W.R. (1960) Least squares analysis of data with unequal subclass numbers. U.S. Dept. Agric. ARS20-8.

Johnson, D.C. \& Hoversland, R.C. (1983) Oestradiol synthesis by granulosa cells from immature rats treated with pregnant mare's serum gonadotropin. Acta endocr., Copenh. 104, 372-380.

Kumari, G.L. \& Channing, C.P. (1979) Intraovarian control of progesterone biosynthesis by granulosa cells and corpus luteum. J. Steroid Biochem. 11, 781790.

Lacroix, E., Eechaute, W. \& Leusen, I. (1974) The biosynthesis of estrogens by cow follicles. Steroids 23, 337-356.

Lamprecht, S.A., Zor, U., Tsafriri, A. \& Lindner, H.L. (1973) Action of prostaglandin E and of luteinizing hormone on ovarian adenylate cyclase, protein kinase and ornithine decarboxylase activity during postnatal development and maturity in the rat. $J$. Endocr. 57, 217-233.

Lieberman, M.E., Barnea, A., Bauminger, S., Tsafriri, A., Collins, W.P. \& Lindner, H.R. (1975) LH effect on the pattern of steroidogenesis in cultured Graafian follicles of the rat: dependence on macromolecular synthesis. Endocrinology 96, 1533-1542.

McNatty, K.P. (1981) Hormonal correlates of follicular development in the human ovary. Aust. J. biol. Sci. 34, 249-268.

McNatty, K.P., Makris, A., de Grazia, C., Osathanondh, R. \& Ryan, K.J. (1979a) The production of progesterone, androgens and oestrogens by human granulosa cells in vitro and in vivo. J. Steroid Biochem. 11, 775779.

McNatty, K.P., Makris, A., de Grazia, C., Osathanondh, R. \& Ryan, K.J. (1979b) The production of progesterone, androgens and estrogens by granulosa cells, thecal tissue, and stromal tissue from human ovaries in vitro. J. clin. Endocr. Metab. 49, 687-699.

Moon, Y.S., Tsang, B.K., Simpson, C. \& Armstrong, D.T. (1978) Estradiol-17 $\beta$ synthesis in cultured granulosa and thecal cells of human ovarian follicles: stimulation by follicle-stimulating hormone. J. clin. Endocr. Metab. 47, 263-267.

Moor, R.M. (1974) The ovarian follicle of the sheep: inhibition of oestrogen secretion by luteinizing hormone. J. Reprod. Fert. 61, 455-463.

Moor, R.M. (1977) Sites of steroid production in ovine Graafian follicles in culture. J. Endocr. 73, 143-150.

Moscona, A. (1961) Rotation-mediated histogenic aggregation of dissociated cells. Expl. Cell Res. 22, 455475.

Orczyk, G.P., Hichens, M., Arth, G. \& Behrman, H.R. (1979) Progesterone and 20-dihydroprogesterone. In Methods of Hormone Radioimmunoassay, pp. 701713. Eds B. M. Jaffe \& H. R. Behrman. Academic Press, New York.

Richards, J.S. \& Midgley, A.R., Jr (1976) Protein hormone action: a key to understanding ovarian follicular and luteal cell development. Biol. Reprod. 14, 82-94.

Rotman, B. \& Papermaster, B.W. (1966) Membrane properties of living mammalian cells as studied by enzymatic hydrolysis of fluorogenic esters. Proc. natn. Acad. Sci. U.S.A. 55, 134-141.

Ryan, K.J. (1979) Granulosa-thecal cell interaction in ovarian steroidogenesis. J. Steroid Biochem. 11, 799800.

Schomberg, D.W. (1979) Steroidal modulation of steroid secretion in vitro: an experimental approach to intrafollicular regulatory mechanisms. Adv. exp. Med. Biol. 112, 155-168.

Schwartz-Kripner, A. \& Channing, C.P. (1979) Changes in responsiveness of porcine granulosa cells to prostaglandins and luteinizing hormone in terms of cyclic AMP accumulation during follicular maturation. Adv. exp. Med. Biol. 112, 137-144.

Short, R.V. (1962) Steroids in the follicular fluid and the corpus luteum of the mare. A 'two cell type' theory of ovarian steroid synthesis. J. Endocr. 24, 59-63.

Steel, R.G.D. \& Torrie, J.H. (1960) Principles and Procedures of Statistics. McGraw-Hill, New York. 
Stoklosowa, S., Gregoraszczuk, E. \& Channing, C.P. (1982) Estrogen and progesterone secretion by isolated cultured porcine thecal and granulosa cells. Biol. Reprod. 26, 943-952.

Suzuki, K. \& Tamaoki, B. (1983) Acute decrease by human chorionic gonadotropin of the activity of preovulatory ovarian $17 \alpha$-hydroxylase and C-17-C20 lyase is due to decrease of microsomal cytochrome $\mathrm{P}-450$ through de novo synthesis of ribonucleic acid and protein. Endocrinology 113, 1985-1991.

Tsang, B.K., Ainsworth, L., Downey, B.R. \& Armstrong, D.T. (1979) Preovulatory changes in cyclic AMP and prostaglandin concentrations in follicular fluid in gilts. Prostaglandins 17, 141-148.

Tsang, B.K., Armstrong, D.T. \& Whitfield, J.F. (1980) Steroid biosynthesis by isolated human ovarian follicular cells in vitro. J. clin. Endocr. Metab. 51, 1407-1411.
Tsang, B.K., Ainsworth, D.T., Downey, B.R. \& Marcus, G.J. (1982a) Differential production of steroids by isolated granulosa and thecal cells in vitro during preovulatory follicular development in the gilt. Biol. Reprod. 26, Suppl. 1, 78, A bstr. 86.

Tsang, B.K., Moon, Y.S. \& Armstrong, D.T. (1982b) Estradiol-17 $\beta$ and androgen secretion by isolated porcine ovarian follicular cells in vitro. Can. J. Physiol. Pharmacol. 60, 1112-1118.

Webh, R. \& England, B.G. (1982) Relationship between LH receptor concentrations in thecal and granulosa cells and in-vivo and in-vitro steroid secretion by ovine follicles during the preovulatory period. $J$. Reprod. Fert. 66, 169-180.

Weiss, M. \& Eckstein, B. (1983) Periovulatory changes in steroid $C_{17.20}$-lyase activity in ovaries of immature rats treated with pregnant mares' serum gonadotropin. Endocrinology 114, 1912-1916.

Received 27 August 1984 